\title{
IV. בllotizen.
}

\section{Staatsrat Dr. von Dorrer.}

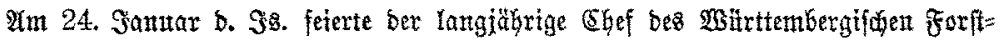

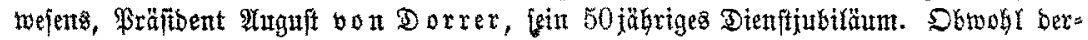

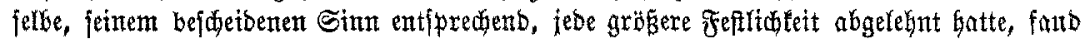

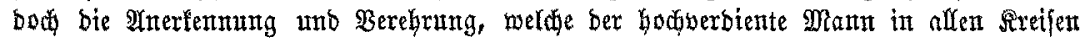

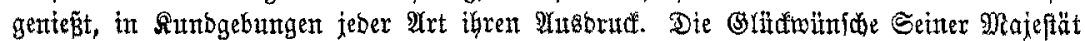

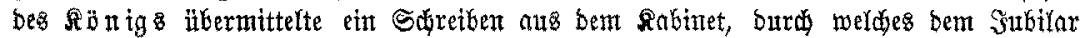

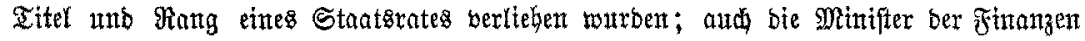

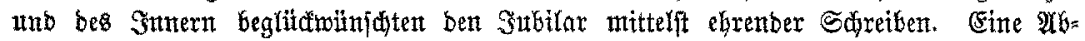
orbuntrg ber Beamten ber Stnatsforfterwaltung, Eeftehenb aus bem Rollegium ber

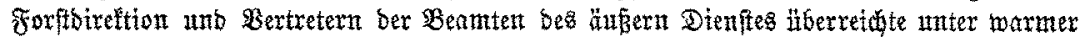

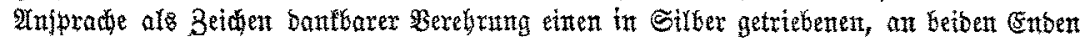

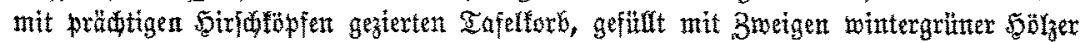

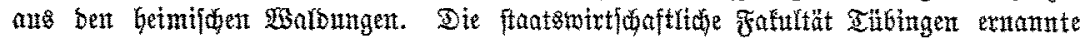

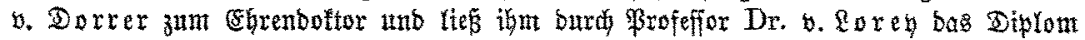

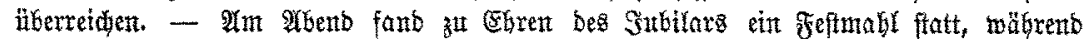

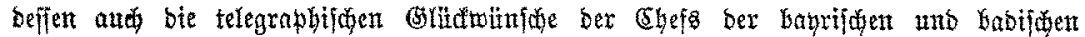
Statefforituerwaltung cinliefen, bie ebenfo wie zaflretde anbere Ielegramnte unto ber

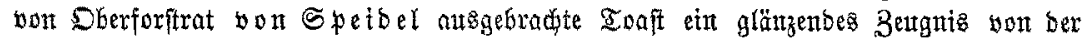
allgemetnent 50 bidfätutng ablegten, beren fto ber Subtlar exfreltt.

Untrittelbar nadf feittent Subeltage trat Stanterat bon Dorrer in ben Ruthe=

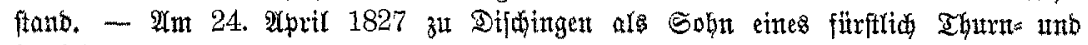

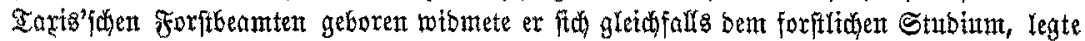
Die Stantsprifung mit vorjitglidjem (Erfolg ab unb fanb ant 24 . Sanuar 1851 peine

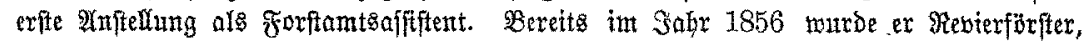
wurbe in Sngr 1858 afs forfifunbige Iffeffor in bie Forftbireftion berufen, 1863 zum

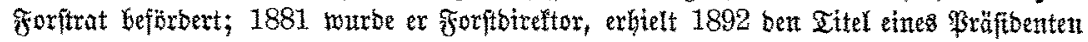

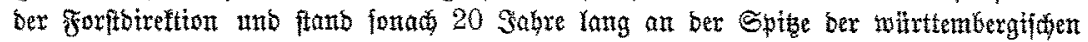

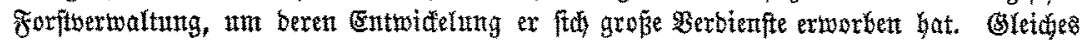
Sntereffe Gat ex bem forftiden Unterridit wie bem forftiden Berfudiswejen entgegent gefradit und betbe in jeber Meife gefördert.

Migge bem bodiberbienten Miante ein langer unb freunblider sebensabeno bes

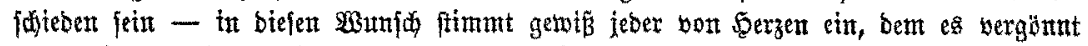

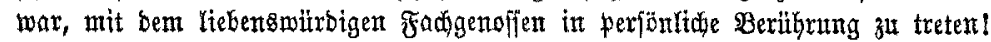

\section{Darmjtädter Kitefernjamen.}

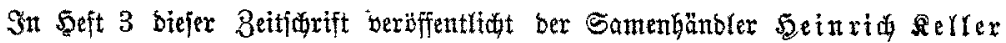
Sobn in Darmftabt einen (Enteberidt unb fudit bei ber Gelegenteit nadzumeifen, baf

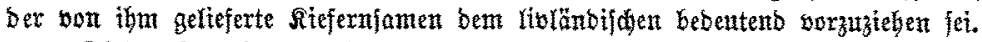

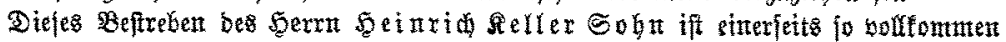

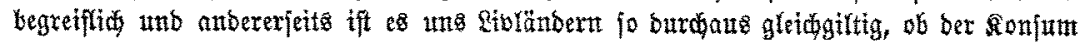

